\title{
動的粘弾性と電気特性によるポリ(エーテル・ウレタン)ハイドロゲルの イオン吸収性能
}

\author{
後藤 和生 ${ }^{* 1} \cdot$ 野口 徹*1 $・$ 山口 良雄 ${ }^{* 1} \cdot$ 出来成人 $* 2$
}

(受付 1991 年 7 月 22 日・審查終了 1991 年 8 月 23 日)

\begin{abstract}
要 旨 ポリエーテルポリゥレタンハイドロゲルの電気伝導度 $(\sigma)$, 及び損失弾性率 $\left(E^{\prime \prime}\right)$ の温度依存性を調べ た. $\sigma$ のアレニゥスプロットにみられる届曲点と, $E^{\prime \prime}$ の温度分散曲線のピークはほぼ同じ温度に観察され，これは ゲルの相転移温度 $\left(T_{\mathrm{p}}\right)$ を示すものと思われる。 $\sigma$ は， $T_{\mathrm{p}}$ 以上の温度では，ゲル中に含まれる自由水に支配され， $T_{\mathrm{p}}$ 以下では低温において東結されない不凍水に强く影掣を受けた。自由水を除いた乾燥ゲルでは，ゲル分子が互いに 不凍水を会して拘束し合い， $T_{\mathrm{p}}$ は高温に移動した．以上より，ゲルの電気伝咅性はゲルの分子運動と対応すること がわかった. 一方, 電解質水溶液中の水, あるいは電解質イオンのゲル中への移行は, 溶液中に存在する陽イオン 種の影辢を強く受け、ゲル, 水, 溶存イオンの 3 者間の相互作用の差異が物質の移行を支配していると思われる. また，塩化カルシウムを含有した乾燥ゲルの $\sigma$ のアレニゥスプロットにおける屈曲点は約 $110^{\circ} \mathrm{C} に ， E^{\prime \prime}$ の温度分 散はプロードなピークが $150^{\circ} \mathrm{C}$ 付近と比較的高温側に各々観察されたことから,ゲル分子と吸収された電解質イオ ンが強く結合することによって極めて剛直な高次構造を形成したものと考えられる.
\end{abstract}

\section{1 緒言}

近年，ポリアクリル酸，ポリビニルアルコール，ポリ アクリルアミドなどの高分子ハイドロゲルの固有の機能 を活かした応用技術開発が盛んに行われ，その応用は紙 おむつ, 生理用品, シーリング剂, 土壤改質剂, 砂漠の 緑化などの広い範囲に及んでいる，さらに，体積相転移 現象の発見 ${ }^{1), 2)}$ 以来数々の興味深い実験が行われ， それ らの応用として各種のアクチュエータ, センサ, 分離膜, 生体用材料, 薬物放出制御剤などの新規技術分野におけ る研究開発も活発に行われている ${ }^{3) \sim 9) . ~}$

これら高分子ハイドロゲルはイオン伝導性を示すこと はよく知られており，その柔軟性と強い粘着力を活かし て各種人体用電極に用いられ，また，前述のようにアク チュエータ，センサへの適用が検討されている。このゲ ルのイオン伝導性は, ゲル分子の構造と分子運動に依存 するのはあちろんのこと, 含有するイオン, 水分によっ て大きく影響を受ける．また，ゲルは大きな力学的減衰 を示すことが知られているが, 弾性率が非常に小さいた めその粘弾性挙動を詳しく調べることは困難である。し かし，ゲルの分子構造と分子運動性に関する情報を直接 与える粘弾性挙動は, イオン伝導挙動を理解するために 重要であり, イオンや水を吸収したゲルの構造を知る上

*1 三ッ星ベルト(株)研究開発部研究課（-653 神戸市長田区 浜添通 4-1-21)

*2 神戸大学工学部工業化学科（657 神戸市灌区六甲台町 11)
でも欠くことのできないものである.

そこで著者らは，ポリエーテルポリウレタンゲルに微 少な繰り返し圧縮変形を与えて粘弾性挙動の温度特性を 求め, 電気伝導度の温度依存性と比較検討を行った。 た, 各種の電解質水溶液にゲルを浸漬して, イオン及び 水の吸収性について調べた。

\section{2 実験}

\section{1 試料の作製}

高分子ハイドロゲルには厚さ $2 \mathrm{~mm}$ のポリエーテルポ リウレタンゲル (PEUG, タキロン(株)製)を用いた. 残 留低分子量成分及び可塑剂などを除去するために $20^{\circ} \mathrm{C}$ のイオン交換水に 24 時間浸漬後, $10^{-3}$ Torr にて 72 時 間減圧乾燥したPEUG を原試料とした。この原試料を 以下に示す各種の水溶液に $20^{\circ} \mathrm{C}$ にて所定時間浸漬後, イオン交換水にて表面を洗浄し，さらに $80^{\circ} \mathrm{C}$ で 3 分間 の乾燥を施したPEUG を『湿潤試料』とした. 原試料を 浸清する水溶液はイオン交換水, アルカリ金属, 及びア ルカリ土類金属の塩化物飽和水溶液及び硝酸塩飽和水溶 液である，また，湿潤試料を $10^{-3}$ Torr にて 72 時間減圧 乾燥したPEUGを『乾燥試料』とした。

\section{2 電気特性}

交流電気特性については, $20 \times 20 \mathrm{~mm}$ に裁断した試料 を Fig. 1(a) に示すように $20 \times 20 \mathrm{~mm}$ の 2 枚の白金電極 で挟み, 所定温度の恒温槽に 30 分間保持した後, LCR メーター（安藤電気(株)製）を用いて $0.1 \sim 100 \mathrm{kHz}$ の周 波数範囲でのインピーダンス $(Z)$ と位相角 $(\theta)$ を求め, 
(a)

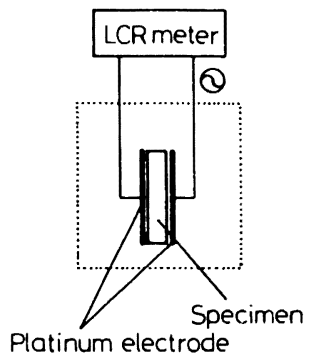

(b)

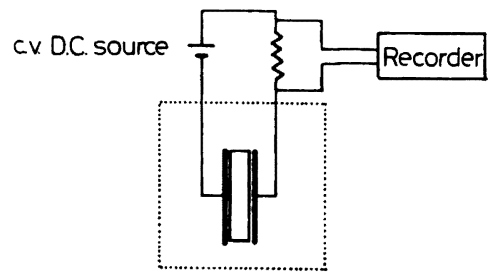

Fig. 1. Schematic diagrams for measuring electrical properties:

(a), for measuring AC properties; (b), for measuring DC properties.

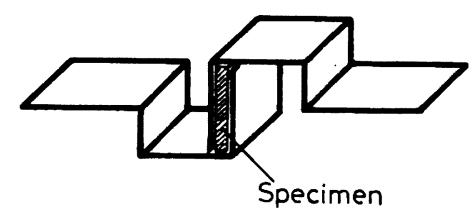

Fig. 2. Scheme of compressive apparatus.

複素インピーダンスプロットから電気伝導度 $(\sigma)$ を計算 した.

直流電気特性については，Fig.1(b) に示すようにポテ ンシォスタット（北斗電工(株)製）を用い，上述のセル を用いて $2 \mathrm{~V}$ 及び $10 \mathrm{~V}$ における電流－時間曲線を測定 した.

\section{3 功的粘弾性}

$8 \times 6 \mathrm{~mm}$ に裁断した厚さ約 $2 \mathrm{~mm}$ の試料を初期荷重 $50 \mathrm{~g}$, 周波数 $10 \mathrm{~Hz}$, 動的歪 $\pm 0.1 \%$ にて厚み方向に圧縮 变形を与え, $-80 \sim 200^{\circ} \mathrm{C}$ の温度範囲で昇温速度 $2^{\circ} \mathrm{C} /$ $\min$ の条件下, 眝蔵弾性率 $\left(E^{\prime}\right)$ 及び損失弾性率 $\left(E^{\prime \prime}\right)$ の温度分散を求めた. 試験器はレオログラフンリッド (東洋精機(株)製)を使用し、圧縮用のチャックの形状は Fig. 2 に示した.

\section{3 結果及ひ考察}

\section{1 気的性僙に及ぼす水の影霓}

Fig. 3 にイオン交換水に 24 時間浸漬して得られた湿 潤試料とこれを減圧乾燥した乾燥試料の直流電気特性を 示した. 印加電圧は $10 \mathrm{~V}$ と, 電流の大きい $50^{\circ} \mathrm{C}$ の湿

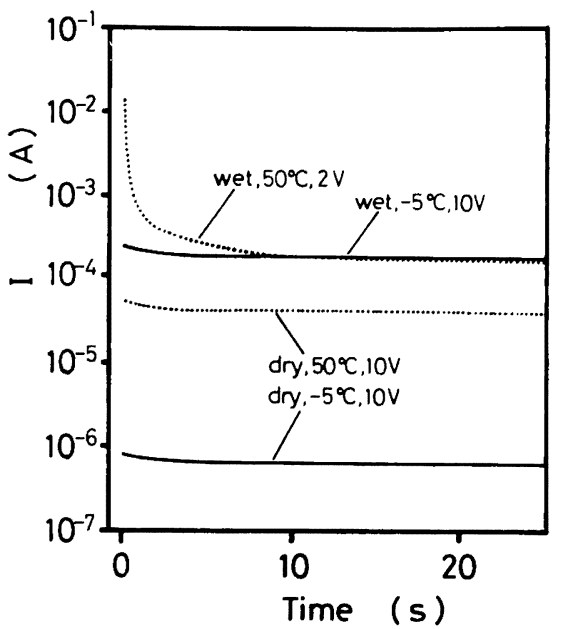

Fig. 3. Electrical current-time relationships for PEUG immersed in deionized water.

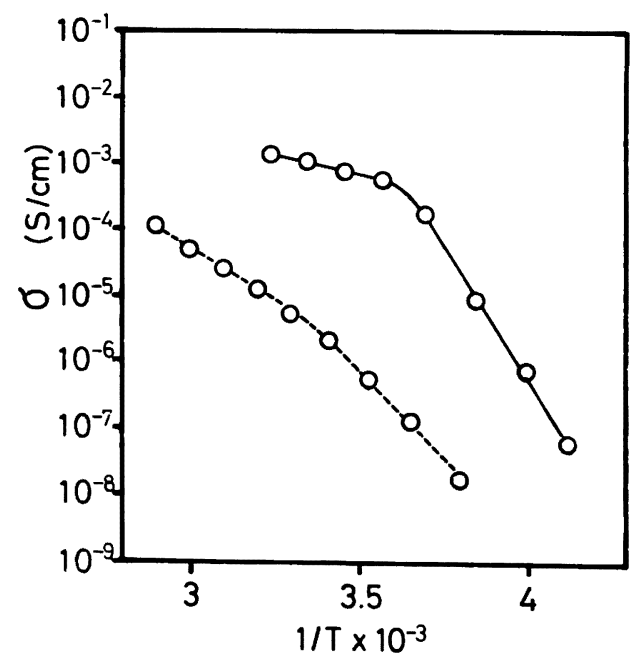

Fig. 4. Arrhenius plots of ionic conductivity for PEUG immersed in deionized water: - - wet PEUG; -.--, dry PEUG.

潤試料のみ $2 \mathrm{~V}$ とした.

大量の水分を含みイオン伝導を示す湿㵎試料は, $50^{\circ} \mathrm{C}$ では電圧印加直後極めて大きい電流か流れ，その後電流 は急激に低下してほぼ一定値となった，水の凝固点以下 の $-5^{\circ} \mathrm{C}$ においても電圧印加直後に大きな電流が流れ, その後低下してほぼ一定値となった。このことは, $-5^{\circ} \mathrm{C}$ においても涷結しない不凍水の存在 ${ }^{10)}$.11)示すすのと 考えられる. 一方, 乾嬠試料は自由水が著しく少ないた め, 電流値は湿潤試料に比へ数析小さく, $50^{\circ} \mathrm{C}$ において あ電流は時間に依存せずほぼ一定の値を示した。

Fig. 4 に電気伝導度 $(\sigma)$ の温度依存性について示し 


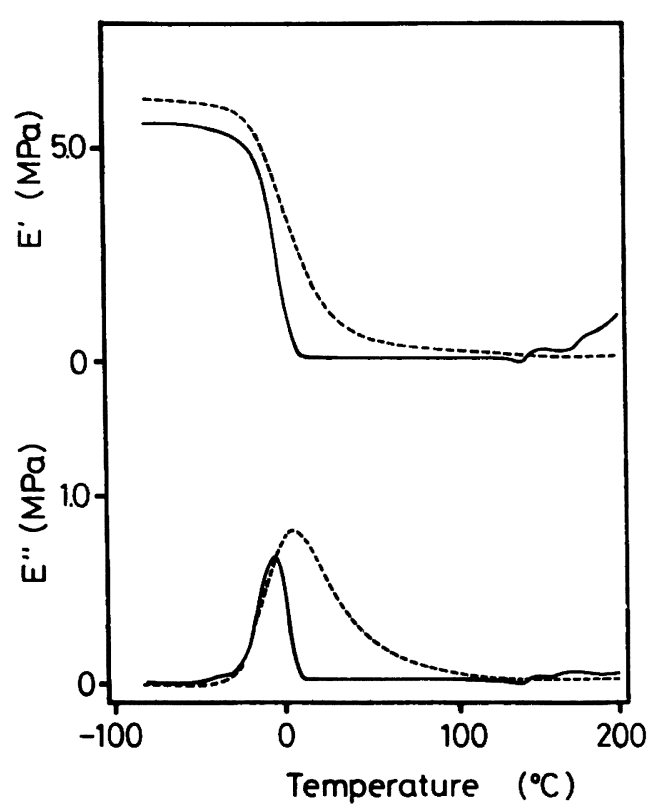

Fig. 5. Temperature dependences of storage moduli and loss moduli for PEUG immersed in deionized water: - , wet PEUG; ----, dry PEUG.

た. 困から湿潤試料, 乾燥試料ともに電気伝導度の温度 依存性は, アレニウスプロットにて屈曲点を有する負勾 眍の 2 本の直線となり，共にイオン伝導によるものと考 えられる. 湿潤試料の場合, 届曲点は $0^{\circ} \mathrm{C}$ 付近にみられ, また，低温側の直線の傾きから計算される見かけの活性 化エネルギーは高温側の見かけの活性化エネルギーに比 べて非常に大きい.このことは, 屈曲点の温度を境とし て電気伝導のメカニスムが大きく変化していることを示

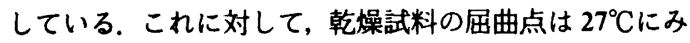
られ，湿閏試料に比べて高温に位置し，また，見かけの 活性化エネルギーは高温側と低温側で大きな変化はな かった。

\section{2 力学的性所に及ぼす水の影霓}

Fig. 5 に湿潤試料之乾燥試料の動的粘弾性の温度依存 性を示した。湿閏試料では, 眝蔵弾性率 $\left(E^{\prime}\right)$ は $0^{\circ} \mathrm{C}$ 付 近で急激に低下し，その後温度が上昇してもはぼ一定の 值を示し, 損失弾性率 $\left(E^{\prime \prime}\right)$ は $0^{\circ} \mathrm{C}$ 付近に鋭いピークを 示した. これらの結果は湿潤ゲルに念まれている多量の 自由水が融解したことを示している.このことから Fig. 4 に示した低温での電気伝尊は部分的に凍結していない 水に起因するイオン伝導であり, 高温では融解した自由 水に起因するイオン伝導であると考えられる. 一方, 乾 熳試料の $E^{\prime}$ は緩やかな低下を示し $E^{\prime \prime}$ は約 $10^{\circ} \mathrm{C} に$ ピークがみられ，血のアレニゥスプロットに見られる届 曲点の温度にほぼ一致している。一般に, ハイドロゲル

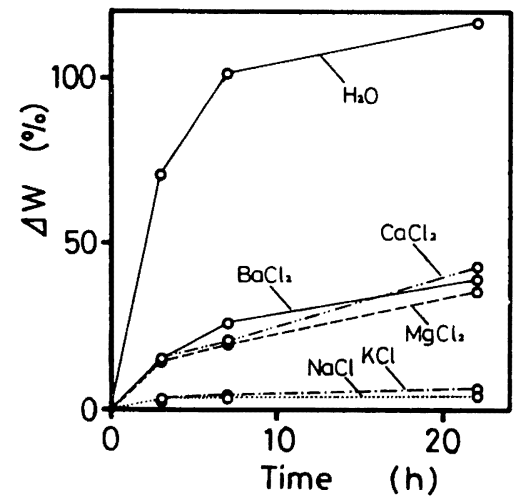

Fig. 6. Changes in weight in accordance with immersing time for wet PEUG in various saturated chloride solutions at $20^{\circ} \mathrm{C}$.

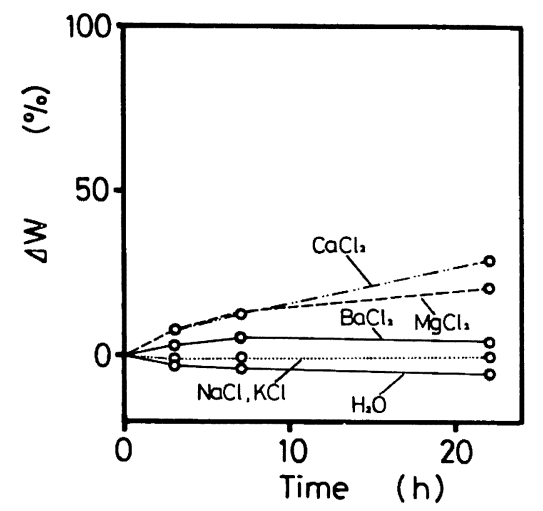

Fig. 7. Changes in weight in accordance with immersing time for dry PEUG in various saturated aqueous chloride solutions at $20^{\circ} \mathrm{C}$.

は自由水と束縛水, さらにその中間的な水を含むことが 知られているが(10) 12)，ここではこの自由水が乾燥に よって取り除かれた結果, $\boldsymbol{E}^{\prime \prime}$ のピークが高温側に移動 したものと考えられる.このように，ハイドロゲルの電 気的特性及び力学的特性はゲルに含まれる水のさまざま な状態をよく反映した結果となった．また，四のアレニ ウスプロットに見られる届曲点の温度及び $E^{\prime \prime}$ の温度分 散曲線にみられるピーク温度はゲルの相転移温度 $\left(T_{\mathrm{p}}\right)$ を示していると思われ，自由水の有無によりゲル分子間 の相互作用が大きく変化していることがよくわかる.

\section{3 ゲルの国解所吸蔵性}

Fig. 6 にイオン交換水, アルカリ金属塩化物飽和水溶 液及びアルカリ土類金属塩化物飽和水溶液に浸清した湿 潤試料の浸漬時間に対する重量変化を示した. イオン交 換水中ではゲルは水を多量に吸収して 24 時間で 2 倍以 上の重量に膨潤した。塩化ナトリウム，塩化カリウムな どのアルカリ金属塩化物飽和水溶液中ではほとんど重量 


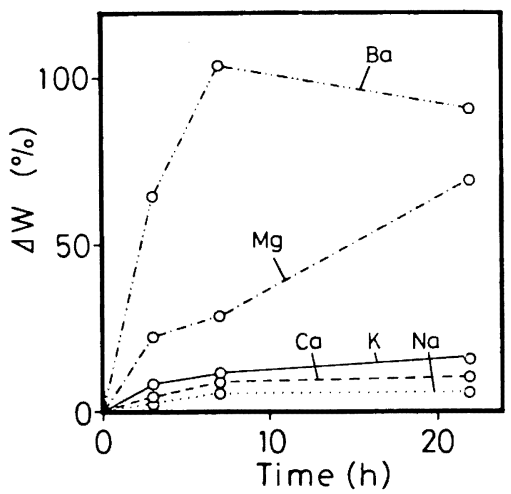

Fig. 8. Changes in weight in accordance with immersing time for wet PEUG in various saturated aqueous nitrate solutions at $20^{\circ} \mathrm{C}$.

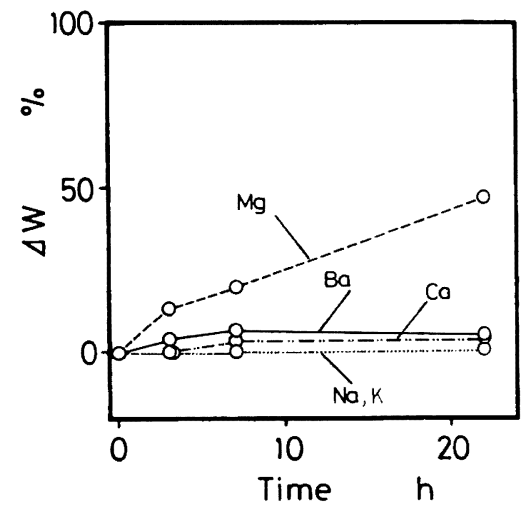

Fig. 9. Changes in weight in accordance with immersing time for dry PEUG in various saturated aqueous nitrate solutions at $20^{\circ} \mathrm{C}$.

が変化しないのに対して, マグネシウム, カルシゥム, バリウムなどアルカリ土類金属塩化物飽和水溶液中で は, 24 時間で 30〜 40\% の重量增加がみられた。

次に, Fig. 6 に示した湿潤試料を減圧乾燥し自由水を 除去した乾燥試料の重量変化を調べ Fig. 7 に示した. イ オン交換水中に浸漬したゲルの重量が減少しているの は, 合成時生成した低分子量成分, あるいは物性改良を 目的として添加されている可塑剂がイオン交換水中に溶 出したためと思われる. アルカリ金属塩化物飽和水溶液 に浸漬したゲルでは，重量変化がほとんど認められず， 水, 或はイオンの吸収はほとんど起こっていないと思わ れる.これに対して，アルカリ土類金属塩化物飽和水溶 液に浸漬したゲルでは，バリウム系を除いて，減圧乾燥 して自由水を取り除いても，なお，大きな重量增加を示 した．以上の結果は次のように説明できる．ゲルはイオ ン交換水中では水を多量に吸収する.これはゲルー水間 相互作用によるものである。しかし，アルカリ金属塩化
Table 1. Changes in weight for PEUG immersed in various saturated electrolyte aqueous solutions at $20^{\circ} \mathrm{C}$ for 24 hours

\begin{tabular}{lccc}
\hline Electrolyte & $\begin{array}{c}\text { Wet gels } \\
W_{w}(\%)\end{array}$ & $\begin{array}{c}\text { Dry gels } \\
W_{\mathrm{d}}(\%)\end{array}$ & $\begin{array}{c}W_{w}-W_{\mathrm{d}} \\
(\%)\end{array}$ \\
\hline $\mathrm{CaCl}_{2}$ & 43 & 29 & 15 \\
$\mathrm{MgCl}_{2}$ & 35 & 20 & 15 \\
$\mathrm{BaCl}$ & 39 & 4 & 35 \\
$\mathrm{KCl}$ & 6 & 0 & 6 \\
$\mathrm{NaCl}$ & 4 & 0 & 4 \\
\hline $\mathrm{Mg}\left(\mathrm{NO}_{3}\right)_{2}$ & 69 & 46 & 23 \\
$\mathrm{Ba}\left(\mathrm{NO}_{3}\right)_{2}$ & 90 & 5 & 85 \\
$\mathrm{Ca}\left(\mathrm{NO}_{3}\right)_{2}$ & 10 & 4 & 6 \\
$\mathrm{KNO}_{3}$ & 15 & 0 & 15 \\
$\mathrm{NaNO}_{3}$ & 5 & 0 & 5 \\
\hline
\end{tabular}

物飽和水溶液中では, ゲルー水間相互作用に比べて, 溶 存イオンー水間相互作用が大きく，また，ゲルー溶存イ オン間相互作用が小さいため, 電解質も, 溶媒である水 も共にほとんど吸収しないものと思われる。一方，アル カリ土類金属塩化物飽和水溶液中では, 溶存イオンー水 間相互作用が比較的小さく，ゲルー溶存イオン間相互作 用が大きいため，水と塩化物の双方を吸収しているもの と思われる．ただ，塩化バリウム飽和水溶液中では，ほ とんど水のみを吸収し塩化物は吸収しなかった。これ は，ゲルー溶存イオン間相互作用が非常に小さいためで あると考えられる. また, 水溶液の $\mathrm{pH}$ 值はゲル浸漬中, 変化がないことから, 塩化物は陽イオンと陰イオンの両 方がゲル中に移動しているものと考えられる。

続いて，アルカリ金属及びアルカリ土類金属の硝酸塩 飽和水溶液中での，ゲルの重量変化を調べた．湿潤試料 については Fig. 8 に, 乾燥試料については Fig. 9 に示し た. 硝酸塩飽和水溶液の場合でも塩化物飽和水溶液と同 様に，ゲルの重量増加率は，アルカリ金属塩とアルカリ 土類金属塩の違いにより大きく異なっている．また，硝 酸バリウム飽和水溶液中でゲルは水のみを吸収した。 ゲ ル中への水の移動は, 水溶液中とゲル中における水の化 学ポテンシャル差に起因すると考えられるので, 水溶液 中の電解質が増加するとゲル中への水の移動量は著しく 低下すると考えられるが，硝酸バリウム䝭和水溶液に浸 漬した場合, 塩化バリウムの場合と同様にゲルー溶存イ オン間相互作用が非常に小さいために水のみを吸収した あのと思わ机、また，先に示したように，塩化カルシ ウムはゲル中に吸収されたが, 硝酸カルシゥムは, アル カリ金属の塩化物及び硝酸塩之同様にほとんど吸収され なかった. Fig. 9 から硝酸マグネシゥムのみが塭化物と 同様に多量にゲル中に移動したことがわかった。

Table 1 に各種水溶液に 24 時間浸漬した試料の重量変 


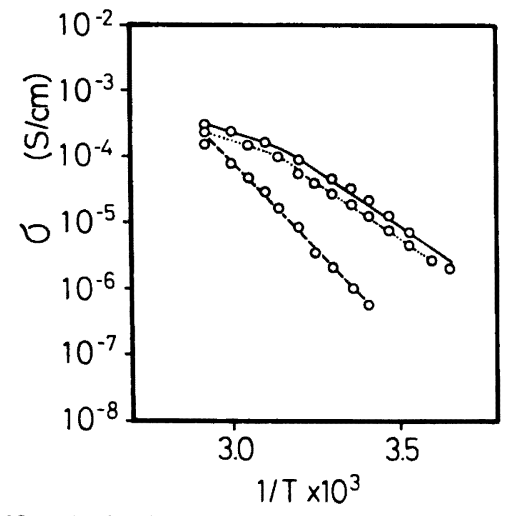

Fig. 10. Arrhenius plots of ionic conductivity for dry PEUG immersed in deionized water ( - ); saturated aqueous $\mathrm{KCl}$ solution (…-.), and saturated aqueous $\mathrm{CaCl}_{2}$ solution (---) at $20^{\circ} \mathrm{C}$ for 24 hours.

化について示した. ここで, $W_{\mathbf{w}}$ 及び $W_{\mathrm{d}}$ はそれぞれ湿潤 試料及び乾燥試料の重量变化率で，前者は水溶液中から ゲル中に移行した水と電解質の合計量を示し，後者は同 じく移行した電解質のみの移動量を示すすので乾燥試料 の灰分率ともほぼ一致した。したがって両者の差 $W_{w}-$ $W_{\mathrm{d}}$ は移行した水の量と考えられる，表から明らかなよ うに，水溶液からゲル中へ，水あるいは電解質の移行す る現象は, 以下の 3 種に大別することができる. 第 1 は, 水も電解質もほとんどゲル中に移行しないもので, これ は陰イオンの種類に関係なくアルカリ金属イオンに共通 してみられる. また硝酸カルシゥムもこれに属してい る. 第 2 に, 電解質イオンが共存しているにもかかわら ず水のみ移行するもので, 陰イオンに無関係にバリウム イオンに特有の現象であった，第 3 は水之電解質が同時 に移行するすので，マグネシウム塩，カルシウム塩の場 合にみられる、特にマグネシウム塩の場合, 塩化物, 硝 酸塩にかかわらず水と電解質の双方の移行が認められ た.

以上のように, PEUG の電解質水溶液中における電解 質と水の吸収性は, 溶存イオンー水間, ゲルー水間, ゲ ルー溶存イオン間に㗢く相互作用の差異により变化し, 陽イオン種の違いが強く影響していると思われる。 た，陰イオン種の影響もカルシウム塩で認められた。

\section{4 解啠を吸収したゲルの性梊}

Fig. 10 に, 電解質及び水がゲル中に移行した塩化カル シゥム飽和水溶液浸漬試料, 電解質及び水がほとんど移 行しなかった塩化カリウム飽和水溶液浸漬試料, そし て, イオン交換水浸漬試料の減圧乾燥後の $\sigma$ のアレニウ スプロットを示した. イオン交換水浸清試料の $\sigma$ のアレ ニウスプロットは先に示したように屈曲点を有する 2 本 の直線からなっている. 塩化カリウム飽和水溶液浸漬試

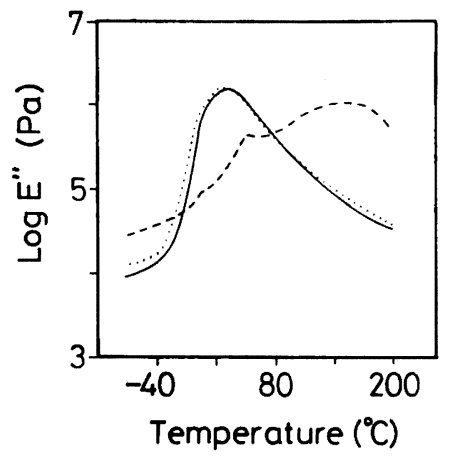

Fig. 11. Temperature dependences of loss moduli for dry PEUG immersed in deionized water ( - ), saturated aqueous $\mathrm{KCl}$ solution ( $\cdots \cdots \cdot$ ), and saturated aqueous $\mathrm{CaCl}_{2}$ solution (---) at $20^{\circ} \mathrm{C}$ for 24 hours.

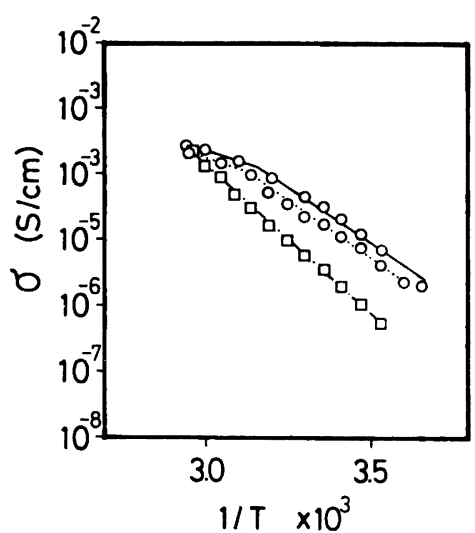

Fig. 12. Arrhenius plots of ionic conductivity for dry PEUG immersed in deionized water ( - ); saturated aqueous NO solution ( $\cdots \cdots \cdot \cdots)$, and saturated aqueous $\mathrm{Mg}\left(\mathrm{NO}_{3}\right)_{2}$ solution (---) at $20^{\circ} \mathrm{C}$ for 24 hours.

料では, イオン交換水浸漬試料とほとんど変わらない結 果となった。一方, 塩化カルシゥム飽和水溶液浸漬試料 では, $0^{\circ} \mathrm{C}$ から $60^{\circ} \mathrm{C}$ の温度範囲では屈曲点か認められ ず，見かけの活性化エネルギーは比較的大きな值となっ た.

同様の試料の損失弾性率の温度分散曲線を Fig. 11 に 示した. 塩化カリウム飽和水溶液浸漬試料は，イオン交 換水浸漬試料と同様に，アレニゥスプロットの屈曲点と

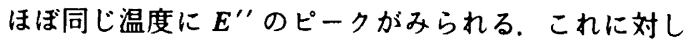
て, 塩化カルシゥム飽和水溶液浸漬試料では, このピー クはブロードに変化し高温側に移動した。この結果か ら，ゲル中に移行したカルシゥムイオン及び塩素イオン の PEUG 分子との強い相互作用のために, より剛直な 高次構造を形成したものと考えられる.

同様の評価を各種硝酸塩飽和水溶液浸漬試料について 行った. 電解質, 及び水がゲル中へ移行する試料として 


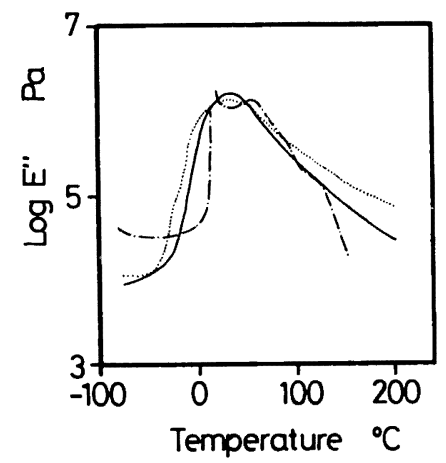

Fig. 13. Temperature dependences of loss moduli for dry PEUG immersed in deionized water ( - ), saturated aqueous KNO solution (…...), and saturated aqueous $\mathrm{Mg}\left(\mathrm{NO}_{3}\right)_{2}$ solution (---·) at $20^{\circ} \mathrm{C}$ for 24 hours.

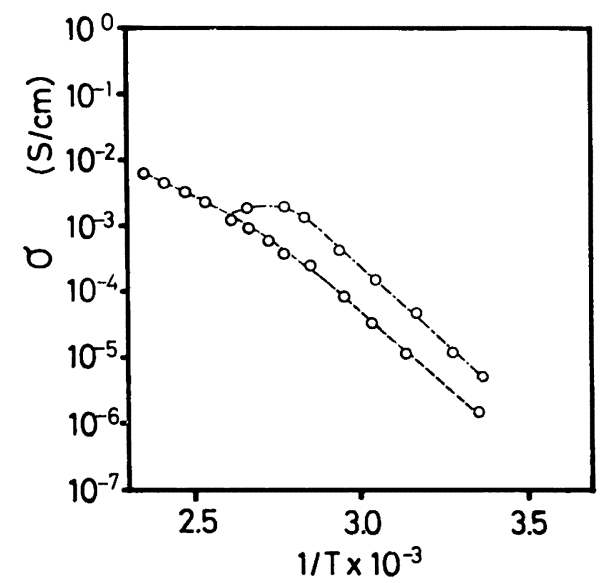

Fig. 14. Arrhenius plots of ionic conductivity for dry PEUG immersed in saturated $\mathrm{CaCl}_{2}$ solution (---) and saturated aqueous $\mathrm{Mg}\left(\mathrm{NO}_{3}\right)_{2}$ solution (…..) at $20^{\circ} \mathrm{C}$ for 24 hours.

硝酸マグネシウム飽和水溶液浸漬試料を, 電解質, 及び 水がほとんど移行しない試料として硝酸カリウム飽和水 溶液浸清試料を用いた。

Fig. 12 にののアレニゥスプロットを, Fig. 13 に $E^{\prime \prime}$ の温度分散曲線を示した，硝酸マグネシウム飽和水溶液 浸漬試料では， $\sigma$ のアレニウスプロットには届曲点はみ られず，見かけの活性化エネルギーも大きく，また $E^{\prime \prime}$ のピークは, 塩化カルシウム飽和水溶液浸漬試料ほよ゙大 きくはないか，高温側に移動した。これに対して，硝酸 カリゥム飽和水溶液浸漬試料では, イオン交換水浸漬試 料と同様の結果となった。

Fig. 10, 12 において, 塩化カルシウム飽和水溶液浸漬 試料及び硝酸マグネシウム飽和水溶液浸漬試料の $\sigma$ の
アレニゥスプロットに, $60^{\circ} \mathrm{C}$ 以下では屈曲点が認められ なかったので，より高温まで測定を行いその結果を Fig. 14 に示した。硝酸マグネシウム飽和水溶液浸漬試料で は, 約 $80^{\circ} \mathrm{C}$ に屈曲点がみられる. しかし, 約 $100^{\circ} \mathrm{C}$ から ゲルの分解液状化が始まったため, それ以上の温度での $\sigma$ の測定はできなかった，一方，塩化カルシゥム飽和水 溶液浸漬試料では分解液状化は起こらず， $110^{\circ} \mathrm{C}$ に屈曲 点が認められた。

これらの結果は，ゲルが電解質及び水を吸収した後に 乾燥されて自由水を失うと, 吸収された電解質とゲル分 子が結合して新しい高次構造を形成し，ゲル分子を拘束 することにより，相転移がより高い温度まで起こらない ことを示し，さらにイオンの種類によってゲル分子との 相互作用は異なっており，このことが電気的特性及び力 学的特性の変化となって現れていることを示している. 本実験では $110^{\circ} \mathrm{C}$ 以上の高温で相転移を起こす塩化カル シゥムを吸収したPEUG と最す剛直な高次構造体を形 成していることがわかった。

\section{4 結論}

ポリエーテルーウレタンハイドロゲルの電気伝導度及 び粘弾性の温度依存性を調べることにより以下に示すこ とがわかった。

1. 電気伝導度のアレニゥスプロットにみられる屈曲 点の温度と損失弾性率 - 温度曲線における極大点の温度 はよく一致している.このことは PEUG のイオン伝導 性がゲル分子の運動性に強く依存することを示してい る. また，これら相転移を示すと思われる温度を境とし て, その電気伝導機構は異なり, さらに含水率, 吸収し た電解質の種類によって転移温度は移動した。

2. 湿潤した PEUG の相転移は, 含有する水の融解に 支配され, 電気的及び力学的性質も含有する水の状態に 支配される. 相転移温度以上では融解した多量の自由水 が，以下では逨結しない不凍水が存在し，これらがイオ ン伝導性に強い影響を及ぼした。

3. PEUG 中への水及び電解質イオンの移行は, ゲ ルー水間, ゲルー溶存イオン間, 溶存イオンー水間の相 互作用の差異により生じており，特に，陽イオン種の違 いが強く影響していると思われる。

4. 乾燥ゲルは溶媒和したゲル分子固有の性質を示 し, さらに吸収した特定の電解質との強い相互作用のた めに $100^{\circ} \mathrm{C}$ を越える高温までその電気伝導機構が变化し ない剛直な複合構造を形成することがわかった。

\section{文献}

1) T. Tanaka, Phys. Rev. Lett., 40, 820 (1978).

2) T. Tanaka, Phys. Rev. Lett., 45, 1636 (1980).

3) 矢島博文, 宮本稔之, 遠藤隆一, 古屋せつ子, 高分子論文 
集, 46, 577 (1989).

4) 石原一彦，上田智子，中林宣彦，高分子論文集，46, 591 (1989).

5)鈴木誠，高分子論文集，46, 603 (1989)

6) K. Umezawa and Y. Osada, Chem. Lett., 1795 (1987).

7) 迫原修治，坂田敏幸，浅枝正司，高分子論文集，46,635 (1989).

8) 原䙾明，相澤益男，高分子論文集，46, 703 (1989).
9）志賀亨, 広瀬美治, 岡田 茜, 倉内紀雄, 高分子論文集, 46, 709 (1989).

10) M. A. Frommer and D. Lancet, J. Appl. Polym. Sci., 15, 1295 (1972).

11) 吉田博久, 畠山立子, 中村邦雄, 畠山兵衛, 高分子論文集, 46, 597 (1989).

12) M. Watase and K. Nishinari, J. Polym. Sci., Polym. Phys. Ed., 23, 1803 (1985).

Viscoelastic and Electrical Properties of Poly(ether-urethane) Hydrogel Absorbing Water or Electrolyte

Kazuo GoroH*1, Toru NoguCHI*1, Yoshio YAMAGUCHI*1, and Shigehito DeKI*2

${ }^{* 1}$ Research and Development Department, Mitsuboshi Belting Ltd. (4-1-21, Hamazoe-dori, Nagata-ku, Kobe, 653 Japan)

${ }^{* 2}$ Department of Industrial Chemistry, Faculty of Engneering, Kobe University (1-1, Rokko-dai, Nada-ku, Kobe, 657 Japan)

The temperature dependences of ionic conductivity $\left(\sigma_{\mathrm{i}}\right)$ and the dynamic viscoelasticity of poly(ether-urethane) hydrogel (PEUG) were studied. The flection point on the Arrhenius plot of $\sigma_{\mathrm{i}}$ and the maximum of loss modulus ( $\left.E^{\prime \prime}\right)$ on the $E^{\prime \prime}$-temperature curve were found at almost the same temperature, which corresponds to the phase transition temperature ( $T_{\mathrm{p}}$ ) of PEUG. The apparent activation energy in the temperature region above $T_{\mathrm{p}}$ was smaller than that in the lower temperature region. In the higher region, the water content in PEUG controlled ionic conduction, and in the lower region, unfrozen water binding the gel molecules controlled it. The $T_{\mathrm{p}}$ of dry PEUG was higher than that of wet PEUG, because dry PEUG contained only bound water, making the structure of PEUG more regid. These results indicate that the ionic conduction of PEUG strongly depends on the molecular motion, while the migration of the water and/or electrolyte into the gel immersed in solution depends on the presence and kind of cations in the solution. The flection point shifted to a much higher temperature around $110^{\circ} \mathrm{C}$ when the gel absorbed $\mathrm{CaCl}_{2}$, and a broad peak of $E^{\prime \prime}$ was observed at a temperature of $c a .150^{\circ} \mathrm{C}$

KEY WORDS Hydrogel / Ionic Conduction / Viscoelasticity / (Received July 22, 1991: Accepted August 23, 1991)

[Kobunshi Ronbunshu, 49(2), 147-153 (1992)] 